\title{
EFFECTS OF PREHEATER LOAD AND LOCATION ON THE CATALYTIC CONVERTER EFFICIENCY DURING COLD START AND IDLING CONDITIONS
}

\author{
Nureddin DINLER ${ }^{*}$, Fatih AKTAS ${ }^{* *}$, Sadullah TASKIN ${ }^{* * * *}$, Salih KARAASLAN $^{* * * *}$ and Nuri YUCEL ${ }^{* * * * *}$ \\ Gazi University, Faculty of Engineering, Department of Mechanical Engineering \\ 06570, Maltepe, Ankara, TURKEY \\ *ndinler@gazi.edu.tr, ORCID: 0000-0002-2872-9050 \\ **fatihaktas@gazi.edu.tr, ORCID: 0000-0002-1594-5002 \\ ***sadullah.taskin@yahoo.com.tr, ORCID: 0000-0002-3935-539X \\ ****karaaslansalih@gazi.edu.tr, ORCID: 0000-0001-7957-2041 \\ *****nuyucel@gazi.edu.tr, ORCID: 0000-0001-9390-5877
}

(Geliş Tarihi: 28.04.2021, Kabul Tarihi: 04.10.2021)

\begin{abstract}
Exhaust emissions are significant pollutants that affect urban lifestyles. There are several regulations related to the exhaust emissions of both gasoline and diesel engines. In this study, the effects of a controlled heating of the exhaust line before the catalytic converter on the converter efficiency are experimentally investigated. Experiments were conducted based on either discrete or cold start conditions. For discrete conditions, the engine was operated until it reached normal and steady state operating conditions. Then, the engine was stopped until the catalytic converter surface temperature reached the ambient temperature. The experiments were first started without additional heating and then continued with different heating loads. In the second stage, the catalytic converter behavior and conversion efficiency under cold start conditions were investigated. The exhaust gas after the exhaust manifold was preheated with different heating loads for the first 150 seconds after the start of the engine; however, the exhaust line was heated $15 \mathrm{~s}$ before starting the engine. The effects of the location, length and heat loads of the electrical resistances on the catalytic converter behavior were investigated. After all of the experiments, it was concluded that with the appropriate location and heating loads, for discrete operating conditions, the hydrocarbon (HC) and carbon monoxide (CO) emission conversion efficiencies reached nearly $100 \%$ after $50 \mathrm{~s}$ of starting the engine. For cold start conditions, the hydrocarbon (HC) and carbon monoxide (CO) emission conversion efficiencies reached $35 \%$ and $80 \%$, respectively.
\end{abstract}

Keywords: Preheating, cold start, emission, idle condition, internal combustion engine, catalytic converter

\section{SOĞUK ÇALIŞMA VE RÖLANTİ KOŞULLARINDA ÖN ISITICI YÜKÜNÜN VE KONUMUNUN KATALITTIK KONVERTÖR VERIMLILIĞIINE ETKILERİ}

Özet: Egzoz emisyonları, kentsel yaşam tarzlarını etkileyen önemli kirleticilerdir. Hem benzinli hem de dizel motorların egzoz emisyonları ile ilgili çeşitli düzenlemeler bulunmaktadır. Bu çalışmada, egzoz hattının katalitik konvertörden önce kontrollü olarak ısıtılmasının konvertör verimine etkisi deneysel olarak incelenmiştir. Deneyler ya kesik ya da soğuk başlangıç koşullarına göre yapılmıştır. Kesik koşullar için motor, normal ve kararlı durum çalışma koşullarına ulaşana kadar çalıştırıldı. Daha sonra, katalitik konvertör yüzey sıcaklığı ortam sıcaklığına ulaşana kadar motor durdurulmuştur. Deneylere önce ilave ısıtma yapılmadan başlanmış, daha sonra farklı ısıtma yükleri ile devam edilmiştir. İkinci aşamada, soğuk çalıştırma koşulları altında katalitik konvertörün davranışı ve dönüşüm verimi incelenmiştir. Egzoz manifoldundan çıkan egzoz gazı, motorun çalıştırılmasından sonraki ilk 150 saniye boyunca farklı 1sıtma yükleriyle ön 1sıtmaya tabi tutulmuştur; ancak egzoz hattı motor çalıştırılmadan 15 saniye önce 1sıtılmaya başlanmıştır. Elektrik dirençlerinin konumu, uzunluğu ve 1sı yüklerinin katalitik konvertör davranış1 üzerindeki etkileri araştırılmıştır. Tüm deneylerden sonra, uygun konum ve 1sıtma yükleri ile, kesikli çalışma koşulları için, hidrokarbon (HC) ve karbon monoksit (CO) emisyon dönüşüm verimlerinin, motorun 50 saniye çalıştırılmasından sonra yaklaşık \%100'e ulaştı̆̆ 1 sonucuna varılmıştır. Soğuk çalıştırma koşulları için, hidrokarbon (HC) ve karbon monoksit (CO) emisyon dönüşüm verimleri sırasıyla \%35 ve \%80'e ulaşmıştır.

Anahtar Kelimeler: Ön 1sıtma, soğuk çalışma, emisyon, rölanti şartları, içten yanmalı motor, katalitik konvertör

\section{NOMENCLATURE}

$\dot{m}_{i n} \quad$ Amount of emissions in the exhaust gas entering the catalytic converter $\dot{m}_{\text {out }} \quad$ Amount of out flow emissions in the exhaust gas from the catalytic converter

$\eta_{\text {cat }} \quad$ Catalytic converter efficiency

$\mathrm{Al}_{2} \mathrm{O}_{3}$ Alumina oxide 


$\begin{array}{ll}\mathrm{CH}_{4} & \text { Methane } \\ \mathrm{cm} & \text { Centimeter } \\ \mathrm{CO} & \text { Carbon monoxide } \\ \mathrm{CO}_{2} & \text { Carbon dioxide } \\ \mathrm{HC} & \text { Hydrocarbon } \\ \mathrm{HP} & \text { Horsepower } \\ \mathrm{i} & \text { Emission index, HC and CO } \\ \mathrm{kW} & \text { kilowatt } \\ \mathrm{mm} & \text { millimeter } \\ \mathrm{MPFI} & \text { Multi Port Fuel Injection } \\ \mathrm{NO} & \text { Nitrogen monoxide } \\ \mathrm{NO} & \text { Nitrogen oxides } \\ \mathrm{O}_{2} & \text { Oxygen } \\ \mathrm{Pd} & \text { Palladium } \\ \mathrm{Ppm} & \text { Parts per million } \\ \mathrm{Pt} & \text { Platinum } \\ \mathrm{Rh} & \text { Rhodium } \\ \mathrm{rpm} & \text { Revolution per minute } \\ \mathrm{s} & \text { Second } \\ \mathrm{SI} & \text { Spark Ignition } \\ \mathrm{TWC} & \text { Three-way Catalyst } \\ \mathrm{V} & \text { Volume }\end{array}$

\section{INTRODUCTION}

Air, soil, and water pollution are a significant concern worldwide. Specifically, vehicle-sourced air pollution is a widely studied subject in urban air pollution. Internal combustion engines operate under transient conditions due to variations in the engine load, and combustion time is extremely short. Therefore, complete combustion cannot be achieved. States are constantly introducing laws and regulations to reduce tailpipe emissions and increase air quality. Structural changes are made to these engines to obtain higher power with less pollutant emissions; however, the engine out emissions cannot be reduced to meet regulatory levels. Thus, three-way catalytic converters, diesel particulate filters, etc., are added to the exhaust systems.

Exhaust emissions are at their highest level during engine start-up operating conditions. Various methods have been applied to reduce the cold start emissions of internal combustion engines. Several publications, including experimental and numerical simulations, can be found in literature (Kalam et al., 2011, Guerrero et al., 2019, Shah et al., 2011, Durat et al., 2013).

The exhaust temperature during the operation of sparkignition engines is approximately $300-400^{\circ} \mathrm{C}$ during idle conditions and $900^{\circ} \mathrm{C}$ at high loads; general operation temperature is between $400-600^{\circ} \mathrm{C}$ with an equivalence ratio of 0.9 - 1.2. Without using a catalyst, the oxidation of $\mathrm{HC}$ and $\mathrm{CO}$ should result in temperatures greater than $600^{\circ} \mathrm{C}$ and $700^{\circ} \mathrm{C}$, respectively. The $\mathrm{HC}$ and $\mathrm{CO}$ exhaust gases' catalytic oxidation can potentially reach $250^{\circ} \mathrm{C}$. For the nitrogen oxide (NOx) emissions, the only satisfactory method includes catalytic processes (Heywood, 1988). Cold start performance, overall cycle performance and aging performance of three-way catalytic converters for the cycles were investigated by Kandylas and Stamatelos (2000). Consequently, it is necessary to use additional methods, such as electrically heated catalysts, so that $\mathrm{HC}$ emissions can meet stringent emission regulations.

$\mathrm{HC}$ and $\mathrm{CO}$ emissions during the cold start of engines comprise the largest segment of the total air polluting emissions. Hence, the automotive industry is faced with environmental regulations to reduce cold start engine emissions. Lafyatis et al. (1998) indicated that HC emissions in the first $60-90 \mathrm{~s}$ of engine operation comprise nearly $80 \%$ of the engine's total HC emissions. This result occurs due to the slower activation of the catalyst material at lower temperatures. To meet the regulations, the exhaust gas temperature should be greater than $150^{\circ} \mathrm{C}$ (Koltsakis, 1997, Latyatis et al., 1998, Illyas et al., 2007). The light-off temperature of a catalytic converter is the temperature at which the catalytic converter efficiency reaches $50 \%$ (Pulkrabek, 2004). There are various speeding techniques to reach the light-off temperature. These techniques can be divided into passive systems and active systems. Passive systems include the position of the catalytic converter, usage of pre-catalysts, HC traps, etc., on the exhaust system. Active systems include the usage of electrically heated catalytic converters, addition of secondary air to the exhaust system, etc., which increase the temperature of the exhaust gas. Horng et al. (2004) used a $150 \mathrm{~cm}^{3}$, fourstroke motorcycle engine to investigate cold start operating conditions using an electrically heated catalytic converter. The position and heating load of the heating elements were considered. It was determined that heating the exhaust gas increased the catalytic converter conversion efficiency; furthermore, when the heating element was located in front of the catalytic converter, the optimal CO conversion efficiency was obtained. Additionally, it was concluded that higher heating loads caused a higher rate of increase for the temperature and $\mathrm{CO}$ conversion efficiency.

In the study performed by Ramanathan et al. (2004), a one-dimensional two-phase model was used to investigate the effects of the light-off efficiency, transition time, and catalyst loading on the optimization of the cold start exhaust emissions. It was concluded that increasing the washcoat thickness with/without catalyst loading increased the efficiency of the catalytic converter. The coating thickness is an important parameter for transition time. Because the coating thickness was less than the optimal thickness, the transition time increased, thus resulting in higher cold start exhaust emission values. To obtain a short light-off time, it was suggested to increase the exhaust gas temperature before the catalytic converter. Additionally, it was indicated that heating the exhaust gas was more efficient than heating the solid parts.

Gong et al. (2011) experimentally studied the efficiency and light-off temperature of a catalytic converter. The effects of the length of the exhaust pipe, ignition timing, and idling speed were investigated. It was concluded that shortening the exhaust pipe increased the inlet temperature, and shortening the light-off time with a 
retarded ignition timing and increased idle speed had positive effects on reducing the $\mathrm{HC}$ and $\mathrm{CO}$ emissions' light-off time. Tyagi and Ranjan (2015) studied a preheated catalytic converter. Experimentally, it was observed that the air pollutant exhaust emissions were reduced by preheating the catalytic converter. This result was due to shortening the delay period of the temperature gain by the catalytic converter. Consequently, the emission characteristics of the $\mathrm{HC}, \mathrm{CO}$, and $\mathrm{NO}_{\mathrm{X}}$ were reduced from 800 to $15 \mathrm{ppm}, 4$ to 0.07 (V/V\%), and 1200 to $115 \mathrm{ppm}$, respectively. It was determined that with sufficient temperatures, the catalysts became highly activated, and the rate of reaction thus increased from the starting phase, which optimized the emission conversion of the pollutants.

Roberts et al. (2014) thoroughly investigated the cold start engine efficiency using potential solutions. It was concluded that the solution for reducing cold start emissions had to satisfy both emission reduction and fuel consumption requirements and be cost effective. Bhattacharyya and Das (1999) reviewed previous studies performed on electrically heated catalysts. Coppage and Bell (2002), Bhaskar et al. (2010) and Sendilvelan and Bhaskar (2016) used specially designed electrically heated catalytic converters in their studies. Coppage and Bell (2002) studied a commercial electrically heated catalytic converter with a secondary air injection. With this configuration, the maximum $\mathrm{CO}$ and $\mathrm{HC}$ conversion efficiencies were obtained. It was demonstrated that electric heating was ineffective for reducing $\mathrm{NOx}$ emissions. In Bhaskar's studies, different materials were tested for the electric heater of an EHC (electrically heated catalytic) catalytic converter with different air injection configurations. In these studies, the $\mathrm{CO}$ and $\mathrm{HC}$ emissions were reasonably reduced (Bhaskar et al., 2010, Sendilvelan and Bashkar, 2016). Furthermore, numerical studies can be found in literature, such as the study performed by Dinler et al (2018). A twenty-four equation reaction model was used to model the chemical reactions inside the catalytic converter. They modeled the cold start emissions and temperature control for an electrically heated catalytic converter. Additionally, the study attempted to control the cold start catalytic converter temperature to achieve fast light-off using different types of controllers.

This study attempted to reduce the cold start $\mathrm{HC}$ and $\mathrm{CO}$ emissions under transient conditions. Thus, electrical heaters were used, and preheating was applied before the catalytic converter. To observe the effects of preheating the heating load, the length and position of the heaters were changed. An investigation of these parameter together with time is unique to this report. Heating the exhaust gas accelerated the time needed to reach the light-off temperature.

\section{EXPERIMENTAL SETUP AND PROCEDURE}

Experiments were conducted at the Internal Combustion Engines and Automotive Laboratory of the Mechanical Engineering Department in Gazi University. The schematic view of the experimental set-up is shown in Figure 1. A four-cylinder, four-stroke multi point fuel injection SI engine was used in the tests. The specifications of the engine are provided in Table 1.

The temperatures were measured using K-type thermocouples on the test bench. The heaters were located before the catalytic converter. The thermocouples were located before and after the heater and after the catalytic converter. Keeping the environmental temperatures the same, the experiments were repeated at least three times.

Table 1. Engine specifications

\begin{tabular}{|l|l|}
\hline Engine Parameters & Specifications \\
\hline Manufacturer and Type & Toyota 1.6, gasoline 4 stroke \\
\hline Number of Valves & 16 \\
\hline Type & In line 4 cylinder, MPFI \\
\hline Bore x Stroke & $80 \mathrm{~mm} \times 77 \mathrm{~mm}$ \\
\hline Displacement Volume & $1599 \mathrm{cc}$ \\
\hline Compression Ratio & $9.5: 1$ \\
\hline Power & $103 \mathrm{HP}$ \\
\hline Max. Torque & $137 \mathrm{Nm} @$ 3200rpm \\
\hline Max. Power & $103 \mathrm{HP} @$ 6000rpm \\
\hline Cooling & Water Cooling \\
\hline
\end{tabular}

SUN MGA 1200 and Capelec CAP 3200 exhaust gas analyzers were used for the $\mathrm{HC}$ and $\mathrm{CO}$ emission measurements. The specifications of the analyzers are provided in Tables 2 and 3. During the preliminary experiments, the difference in the response time between the SUN MGA 1500 and the Capelec CAP 3200 exhaust gas analyzers was observed to be approximately 15 seconds. Based on this response time of the gas analyzers, the interval between two measurements was selected to be 15 seconds, and the measurements were performed for 150 -second sets and repeated. And the mean values were taken as the measurement values, i.e., the temperature and exhaust gas emission values before and after the catalytic converter. Equation 1 was used to calculate the conversion efficiency of the catalytic converter.

$\left(\eta_{\text {cat }}\right)_{i}=\frac{\left(\dot{m}_{\text {in }}\right)_{i}-\left(\dot{m}_{\text {out }}\right)_{i}}{\left(\dot{m}_{\text {in }}\right)_{i}}$

The experiments were conducted in two stages. In the first stage, the engine was operated under cold start conditions without additional heating, and the efficiency of the catalytic converter was observed. The first 150 seconds of engine operation was considered to measure the emissions, as stated in the literature (Mahadevan et al., 2017). Measurements were taken when the engine was not loaded at the idle speed (approximately 1000 rpm). Unleaded gasoline was used, and the engine was controlled using an electrical dynamometer (Figure 1). 


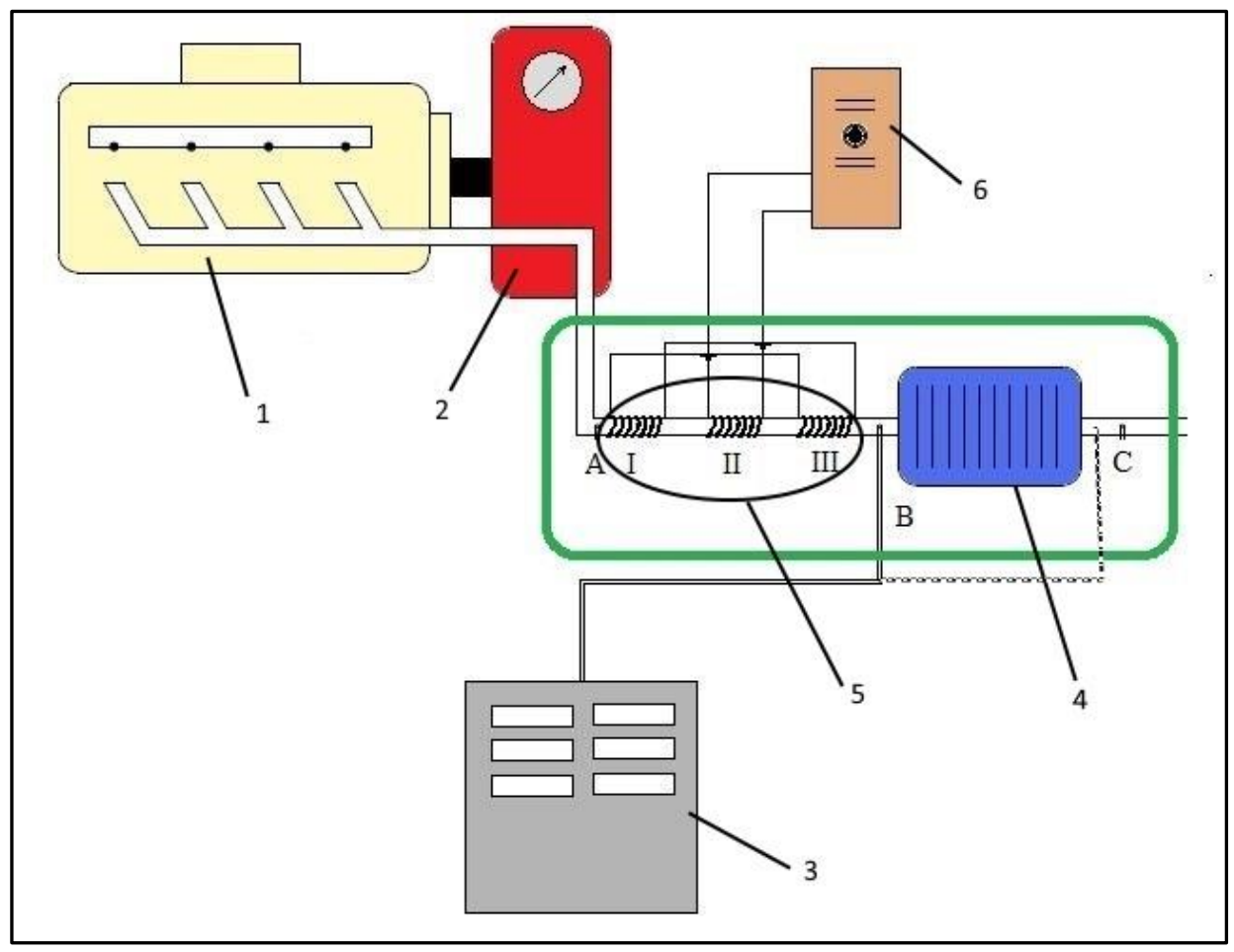

Figure 1. Schematic view of the test bed. 1. Engine; 2. Dynamometer; 3. Exhaust gas analyzer; 4. Three-way catalytic converter; 5. Resistances; and 6. Voltage Adjustable Regulator (Three-phase Variac).

Table 2. Specifications of the Sun MGA-1200 emission analyzer.

\begin{tabular}{|l|l|l|l|}
\hline \multicolumn{1}{|c|}{ Parameter } & $\begin{array}{c}\text { Measurements } \\
\text { range }\end{array}$ & Accuracy & Uncertainty \\
\hline $\mathrm{CO}(\%$ vol. $)$ & $0-10$ & 0.01 & $\% 4$ \\
\hline $\mathrm{CO}_{2}(\%$ vol. $)$ & $0-20$ & 0.01 & $\% 4$ \\
\hline $\mathrm{HC}(\mathrm{ppm})$ & $0-20000$ & 1 & $\% 4.4$ \\
\hline $\mathrm{O}_{2}(\%$ vol. $)$ & $0-21$ & 0.1 & - \\
\hline
\end{tabular}

Table 3. Specifications of the Capelec Cap 3200 emission analyzer.

\begin{tabular}{|l|l|l|l|}
\hline Parameter & $\begin{array}{l}\text { Measurements } \\
\text { range }\end{array}$ & Accuracy & Uncertainty \\
\hline $\mathrm{HC}(\mathrm{ppm})$ & $0-20000$ & 1 & $\% 4,4$ \\
\hline $\mathrm{CO}_{2}(\%$ vol. $)$ & $0-20$ & 0.1 & $\% 4$ \\
\hline $\mathrm{CO}(\%$ vol. $)$ & $0-15$ & 0.001 & $\% 4$ \\
\hline $\mathrm{O}_{2}(\%$ vol. $)$ & $0-21.7$ & 0.01 & - \\
\hline
\end{tabular}

In the experiments, the first 150 seconds after the engine started was defined as the cold start regime. The measurements were taken at 15 -second intervals without any modifications to the exhaust line. First, the engine was started and operated until it reached normal and steady state conditions. Then, the engine was stopped until the surface temperature of the catalytic converter reached the environment temperature. This was done to simulate the actual operating conditions of the engine. The experiments were conducted ranging from nonheating conditions to different preheating conditions for cold start engine operation. To minimize measurement errors, the experiments were repeated at least three times. During the experiments, the temperature measurements were obtained using thermocouples from three positions: engine out (A), before the catalytic converter (B) and after the catalytic converter (C) as seen in Figure 1. Additionally, the exhaust gas emission analyzers were connected to points before the catalytic converter (B) and after the catalytic converter $(\mathrm{C})$. To define the reference exhaust gas emissions without heating before the catalytic converter inlet (B), both exhaust gas analyzers were used to measure the exhaust gas emissions. It was determined that one of the exhaust gas analyzer's response was faster than that of the other analyzer. The cold engine conditions' reference measurement experiments were conducted five times, and reference values were determined by taking the average of each time step. For the cold operating condition experiments, both the engine and the catalytic converter were cooled to ambient conditions. The engine oil and ambient temperatures were measured and compared with the ambient temperature to verify that the engine had reached ambient conditions. Each experiment was conducted after this condition was satisfied.

In the second stage, gradual (fractional) preheating was applied to the exhaust gas before the catalytic converter, and the same set of experiments were repeated. The exhaust line was insulated with ceramic fiber material up to the inlet of the catalytic converter to retain the temperature of the exhaust gas. Then, heating was performed under these conditions. To increase the temperature of the exhaust gas, two $2 \mathrm{~kW}$ electric resistances were used (with three different positions). The resistances were controlled using a voltage adjustable regulator. By adjusting the voltage, different current values passed over the resistances, and different temperatures of the exhaust gas were obtained. Additionally, these heater resistances were located at 
different positions on the exhaust line, and the effects of these positions were tested.

The insulated electric heaters were out of order due to high temperatures. The electrical heaters were changed and the insulation was removed to have healthy experiment conditions. However, due to incomplete insulation and environmental conditions, the heating resistors are located on the outer surface of the exhaust line; consequently, approximately $35 \%$ of the heating energy was transferred to the exhaust gas.

\section{RESULTS AND DISCUSSION}

\section{Discrete Operation Carbon Monoxide Emissions}

The exhaust gas temperature and emissions were measured before and after the catalytic converter. The results of the $\mathrm{CO}$ conversion efficiency of the catalytic converter for both non-preheated and preheated conditions are provided in Figure 2.

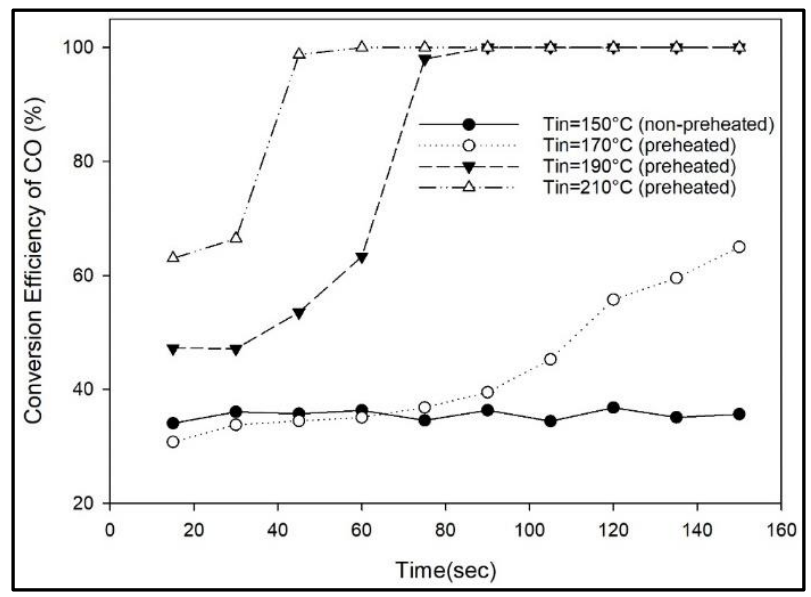

Figure 2. $\mathrm{CO}$ conversion efficiency for non-preheated $\left(150^{\circ} \mathrm{C}\right)$ and preheated conditions for different inlet temperatures.

From the cold start condition $\left(150{ }^{\circ} \mathrm{C}\right)$ without preheating, the catalytic converter was cooled to ambient temperature. Although the catalytic converter surface temperature decreases to ambient temperature, the internal surface temperatures of the catalyst remain higher than the ambient temperature. These conditions are defined as discrete test conditions. Under these conditions, the catalytic converter $\mathrm{CO}$ conversion efficiency was calculated as $35 \%$. The reason for this is related to the fact that the measurement point (point A) was approximately $1.2 \mathrm{~m}$ away from the engine output. In other words, for the first 150 seconds, the increased temperature of the engine could not increase the inlet temperature due to the long distance between them. In addition, the conversion efficiency remained constant, since the inlet temperature could not reach the operating temperature of the catalytic converter with $50 \%$ efficiency in the first 150 seconds. When the exhaust gas was preheated to $170{ }^{\circ} \mathrm{C}$, the $\mathrm{CO}$ conversion efficiency was approximately $37 \%$. After $110 \mathrm{sec}$, when the lightoff temperature was reached, the $\mathrm{CO}$ conversion efficiency was $65 \%$. When the preheated exhaust gas temperature was $190{ }^{\circ} \mathrm{C}$, the $\mathrm{CO}$ conversion efficiency reached $100 \%$ at the $80^{\text {th }}$ second. This result is a result of the discrete operation of the engine. Due to the discrete engine operation and the washcoat being insufficiently cooled, the conversion efficiency with preheating reached its maximum value in a short period of time.

When the preheated exhaust gas temperature was $210^{\circ} \mathrm{C}$ before the catalytic converter under idle conditions, the maximum conversion efficiency was obtained at approximately $50 \mathrm{sec}$. This result indicates that all of the $\mathrm{CO}$ emissions were oxidized to $\mathrm{CO}_{2}$ emissions. According to these results, discrete engine operation and preheating has the same favorable effects on the $\mathrm{CO}$ conversion efficiency as that during steady operation of the engine. Additionally, the values obtained from the experiments were reviewed for an uncertainty analysis. Based on the uncertainty analysis, a $4.3 \%$ uncertainty was obtained for the $\mathrm{CO}$ conversion efficiency.

\section{Discrete Operation Hydrocarbon Emissions}

Due to low temperatures, SI engines produce a higher amount of HC emissions operating on idle and partial loads compared to that under full load operation. Furthermore, an engine operating on a fuel-rich mixture produces more HC emissions. Partial load (partial open throttle) operation is a source of $\mathrm{HC}$ emissions as well. The combustion chamber wall temperature affects the formation of the $\mathrm{HC}$ emissions. The cooling of the wall causes incomplete combustion and increases the $\mathrm{HC}$ emissions. The oxidation of the $\mathrm{HC}$ emissions depends on the post-combustion temperature, duration of combustion gases in the cylinder and exhaust manifold, and oxygen amount in the cylinder. The HC conversion efficiency was examined for cold start and preheated discrete engine operation regimes. The results of the conversion efficiency, which were calculated based on the non-preheated and preheated operating conditions of the repeated experiments, are provided in Figure 3.

As expected, the conversion efficiency of the $\mathrm{HC}$ in a similar temperature range under steady state conditions shows a change comparable to that of the $\mathrm{CO}$ conversion efficiency. This result can be seen in the figures. However, when the graph is examined, the conversion efficiency curves of the non-preheated $\left(150^{\circ} \mathrm{C}\right)$ and preheated $\left(170^{\circ} \mathrm{C}\right)$ conditions have similar trends. The reason for this is related to the fact that the measurement point (point A) was approximately $1.2 \mathrm{~m}$ away from the engine output. In other words, for the first 150 seconds, the increased temperature of the engine couldn't increase the inlet temperature due to the long distance between them. In addition, the conversion efficiency remained constant, since the inlet temperature could not reach the operating temperature of the catalytic converter with $50 \%$ efficiency in the first 150 seconds. For the $170^{\circ} \mathrm{C}$ preheated conditions at 110 seconds, the $\mathrm{CO}$ conversion efficiency reached the light-off temperature; however, the $\mathrm{HC}$ conversion efficiency did not reach values similar to that as the $\mathrm{CO}$ conversion efficiency. This was due to the $\mathrm{CO}$ emissions reaching the light-off temperature 
faster than the $\mathrm{HC}$ emissions. For the $170^{\circ} \mathrm{C}$ preheated conditions, 150 seconds was not enough time to reach the light-off temperature for the $\mathrm{HC}$ emissions, which is why the $\mathrm{HC}$ conversion efficiency was similar to the nonpreheated $150^{\circ} \mathrm{C} \mathrm{HC}$ conversion efficiency. In the study performed by Guojiang and Song (2005), similar results were obtained. The light-off efficiencies of the $\mathrm{CO}$ and $\mathrm{HC}$ emissions were reached between approximately 80 and 110 seconds.

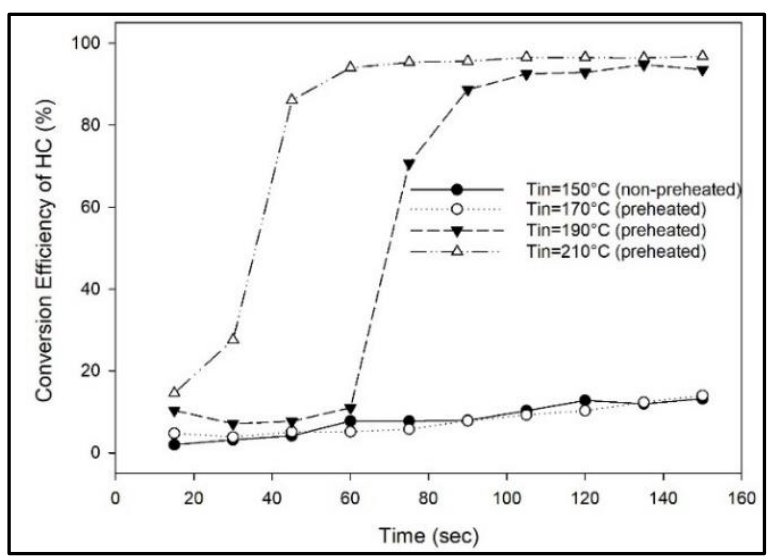

Figure 3. HC conversion efficiency for non-preheated $\left(150^{\circ} \mathrm{C}\right)$ and preheated conditions for different inlet temperatures.

When the exhaust gas entered the catalytic converter at approximately $190^{\circ} \mathrm{C}$, the light-off temperature was reached at 70 seconds, and a $90 \%$ conversion efficiency was reached after 90 seconds. Similarly, when the inlet temperature of the catalytic converter reached $210^{\circ} \mathrm{C}$, the light-off temperature was reached in less than 35 seconds, and a conversion efficiency of $90 \%$ was reached after 35 seconds. However, the uncertainty values should be considered (uncertainty for the HC conversion efficiency is $4.4 \%$ ). Based on these results, discrete operating conditions with preheating has favorable effects on the HC conversion efficiency, and it is believed that steady state engine operation catalytic converter conversion efficiencies can be obtained.

\section{Conversion Efficiencies of the Catalytic Converter under Cold Operating Conditions}

After the discrete motor operation tests were completed, cold start motor operation tests were performed. The effects of the location of the heaters, load and length of the heater sources were examined parametrically. The heaters at different positions were connected to a Variac and heated based on the experimental conditions. Three different heat load condition tests were conducted for the position and length of each resistance.

\section{Effects of the Heater Positions}

To examine the effects of the heater locations, $2 \mathrm{~kW}, 2.4$ $\mathrm{kW}$ and $3 \mathrm{~kW}$ of energy was supplied to the resistances at positions I, II and III, respectively. The experiments were conducted at idle speed (1000 rpm) without a load. The exhaust emissions were measured using the SUN MGA 1200 gas analyzer at point C after the catalytic converter. At the same time, temperature measurements were performed at points $\mathrm{A}, \mathrm{B}$ and $\mathrm{C}$. The emission conversion graphs are provided in the following figures for the heater resistances placed in positions I, II and III. The catalytic converter conversion efficiency, which was obtained by heater I and is the most distant resistance to the converter, is provided in Figure 4(a) and Figure 5(a).

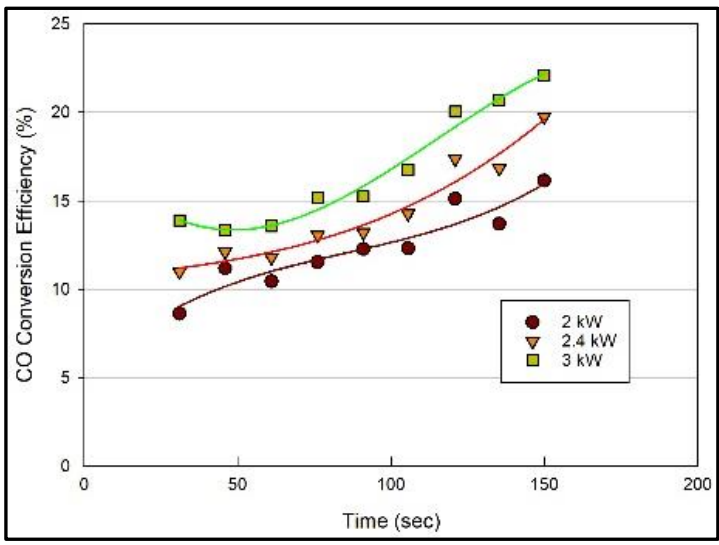

(a)

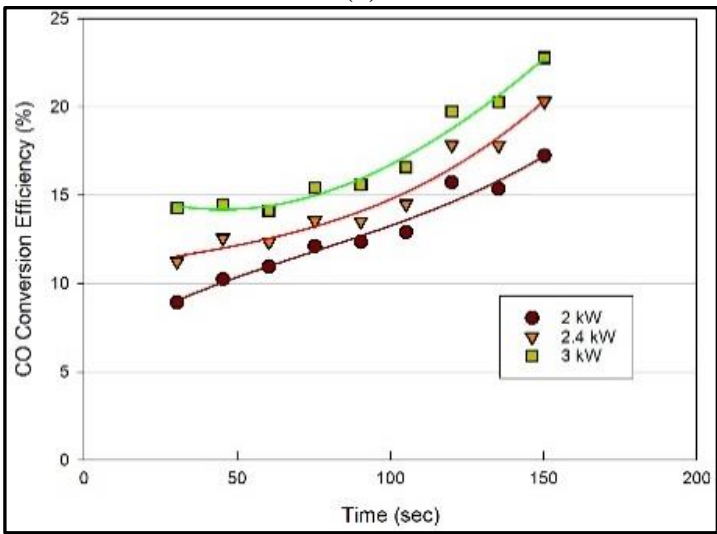

(b)

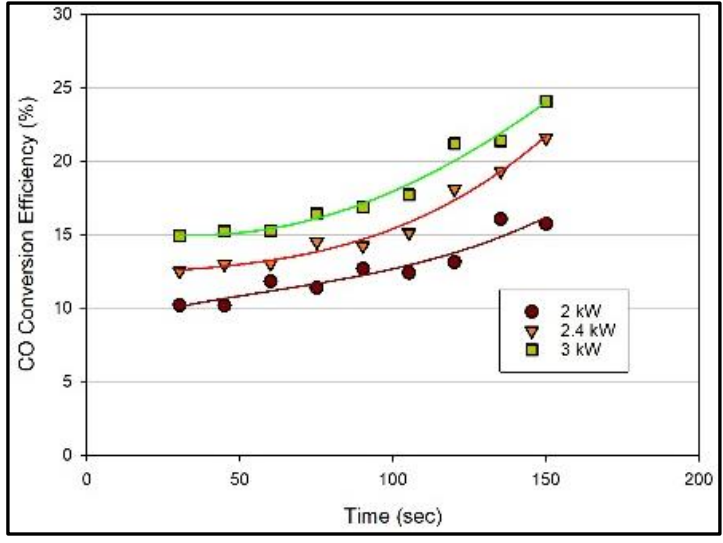

(c)

Figure 4. CO conversion efficiency graph for (a) position I (b) position II (c) position III.

When these figures are examined, it is possible to assume that a low conversion efficiency was obtained. Because the insulating material wrapped on the resistors becomes unusable, most of the heat generated by the resistors cannot be transferred to the exhaust gas. Based on theoretical calculations, only $35 \%$ of the generated heat was transferred to the exhaust gas. The efficiency of the reduction in the carbon monoxide increased with respect 
to time because the exhaust gas was heated between the engine and the catalytic converter. Consequently, heating the exhaust gas before the catalytic converter was faster, and the efficiency was increased. Additionally, the engine had no load under idle conditions, which was when these results were obtained.

The conversion efficiencies of the carbon monoxide and the hydrocarbon gases for heater position II are provided in Figures 4(b) and 5(b), respectively.

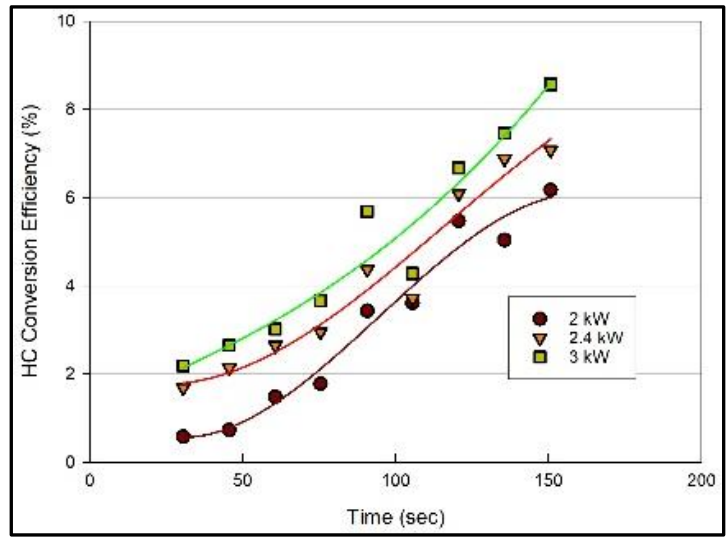

(a)

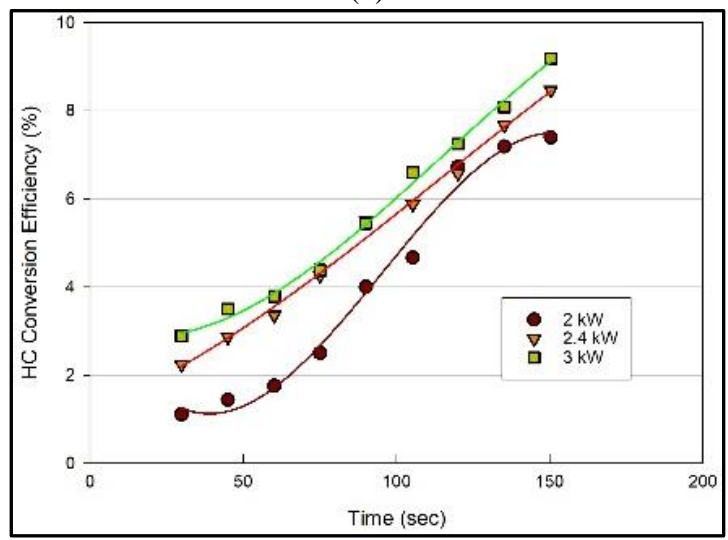

(b)

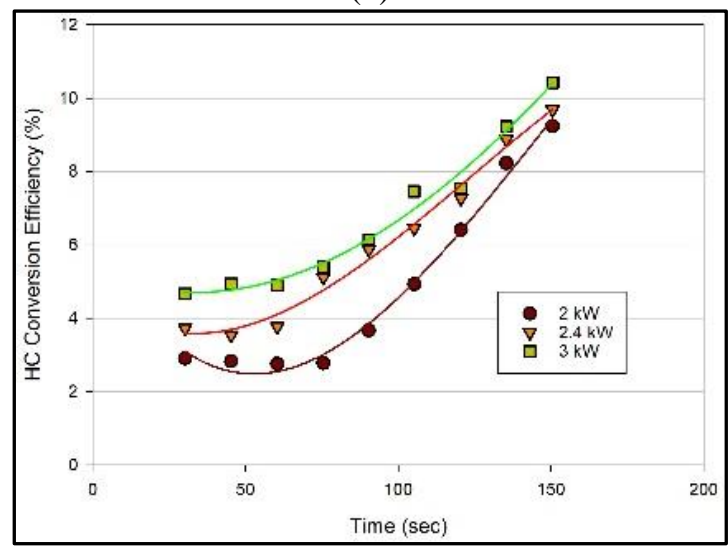

(c)

Figure 5. HC conversion efficiency graph for (a) position I (b) position II (c) position III

Increasing the amount of energy in the heaters increased the conversion efficiency of the catalytic converter. Because position II is closer to the catalytic converter than position I, the heat loss between the catalytic converter and the heater in the exhaust pipe portion is less, thus increasing the conversion efficiency.

When the efficiency of the conversion efficiency is examined at position III, the efficiency values of $\mathrm{CO}$ and $\mathrm{HC}$ are higher than that at the other two positions (Figures 4(c) and 5(c)). When all of the data are examined together, the conversion efficiency is proportional to the distance between the heater and the catalytic converter (Figures 6 and 7). The conversion efficiency increases when the heater's position is close to the catalytic converter. This result occurs because the temperature of the exhaust gas entering the catalytic converter is higher due to lesser heat loss as compared to that in the exhaust pipe. Furthermore, this increases the internal temperature of the catalytic converter.

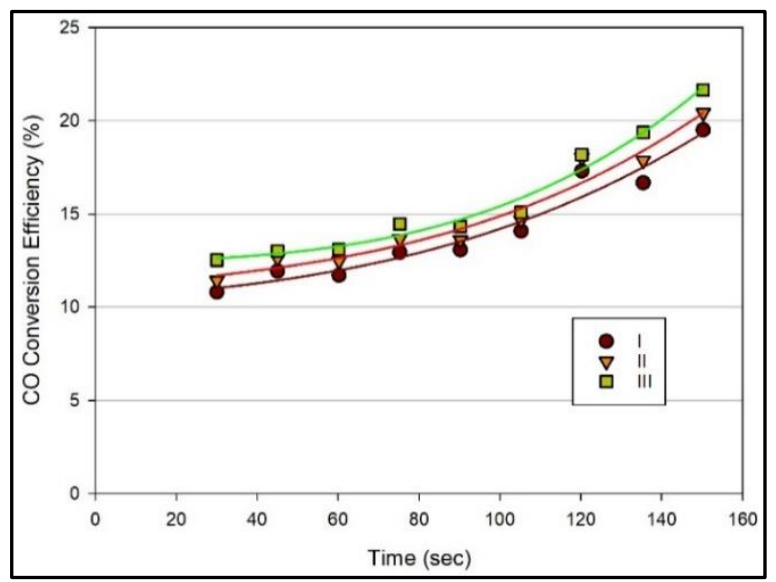

Figure 6. CO conversion efficiency graph for a $2.4 \mathrm{~kW}$ heating load.

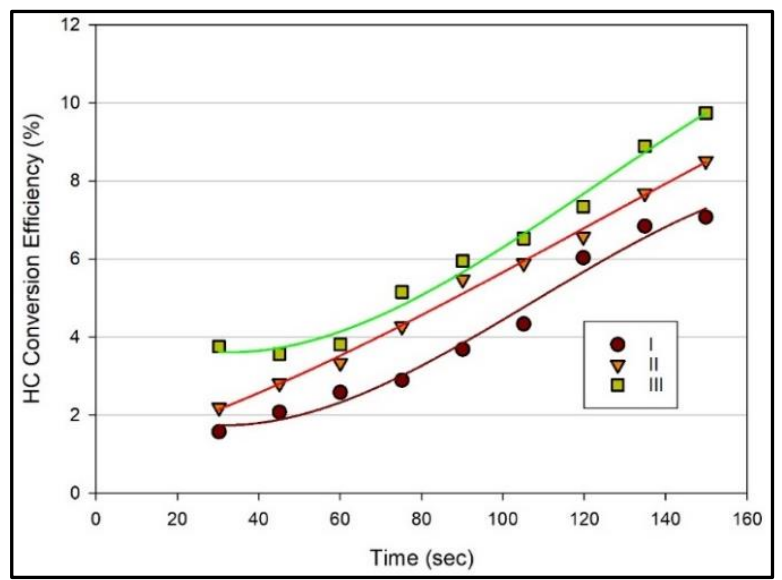

Figure 7. HC conversion efficiency graph for a $2.4 \mathrm{~kW}$ heating load.

Figure 8 illustrates a time-dependent variation of the catalytic converter temperatures without heating and when the heaters in positions I, II and III are operated. As the heater position approaches the catalytic converter, the converter temperature increases. 


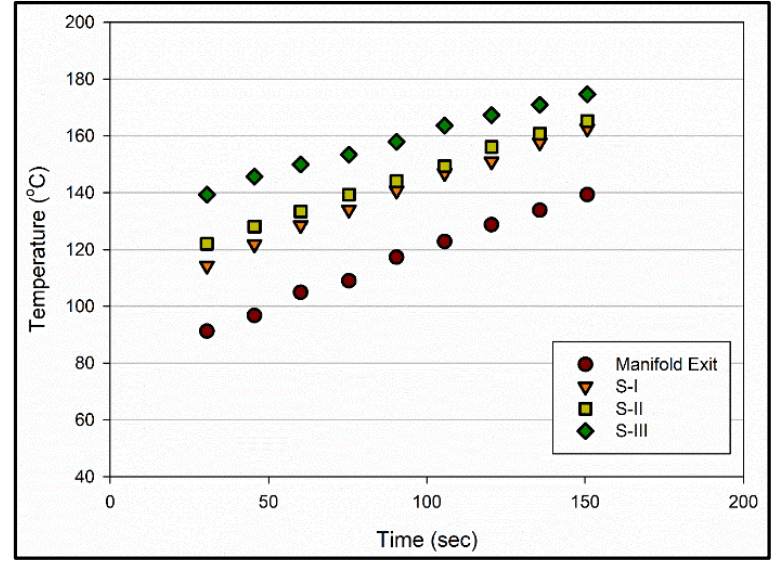

Figure 8. Temperature graph for a $2.4 \mathrm{~kW}$ heating load.

\section{Determining the Effects of the Heater Length}

To determine the effects of the heater neck, the heaters were operated in pairs, i.e., the heaters in positions I and II and the heaters in positions II and III were operated together and tested. The emission conversion efficiencies of these tests are provided in Figures 9 and 10. A total of $3.5 \mathrm{~kW}$ of heat was produced from the double heaters.

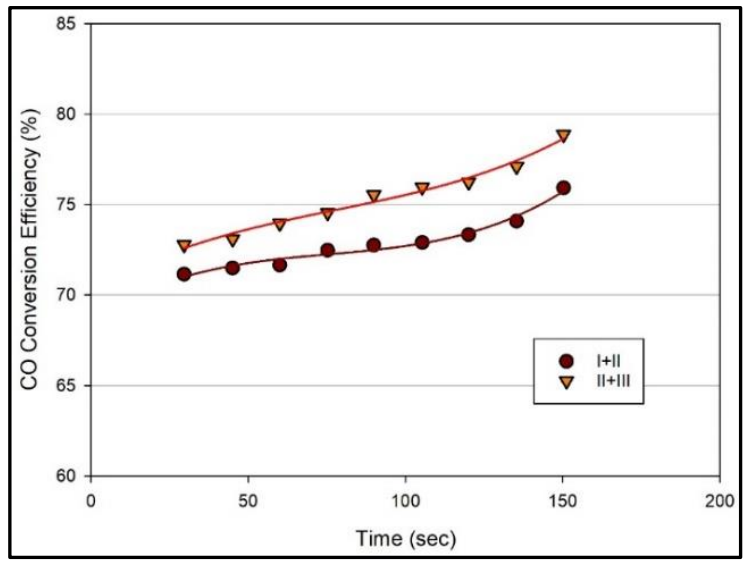

Figure 9. CO conversion efficiency graph for heaters used in pairs.

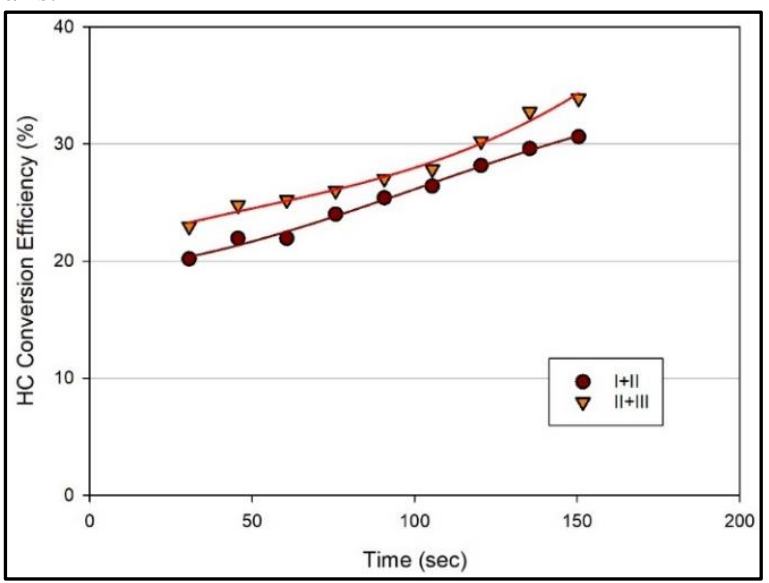

Figure 10. HC conversion efficiency graph for heaters used in pairs.

The heat transfer from the heaters increased with an extension in the length of the heaters, which can be seen in Figures 9 and 10. Increasing the wall temperature of the exhaust line heated up the gas inside it, thus warming the monolith inside the catalytic converter. Consequently, both the warm monolith and the heated exhaust gas increased the conversion efficiency. When the heaters at positions II + III were used at the same time, the conduction heat transfer mode was also effective, which resulted in higher conversion efficiencies. Additionally, increasing the length of the heaters decreased the heat loss to the environment, which helped increase the conversion efficiencies.

\section{CONCLUSION}

Experiments were conducted under both discrete and cold start operating conditions. Under discrete operating conditions, the engine was operated normally to reach steady state operating conditions. By preheating the exhaust gas to higher temperatures, elapsed time to reach light-off efficiency was shortened.

Then, in the second part of the study, the catalytic converter behavior and conversion efficiencies were investigated under cold start operating conditions. At the beginning of the cold start engine operation, the conversion efficiencies were zero. After preheating, both the $\mathrm{CO}$ and $\mathrm{HC}$ emission conversion efficiency values increased. The catalytic converter efficiency increased for all of the preheating conditions over time because the temperature of the exhaust gas increased over time. In the tests, which were conducted to determine the effects of the position of the heaters on the exhaust line, when the heaters were close to the catalytic converter, it was observed that the conversion efficiency increased. This result was assumed to be due to conductive heat transfer from the heater to the catalytic converter, which helped increase the washcoat temperature faster. When all of results were evaluated together, it was determined that heaters with optimum length and preheating loads should be closer to the catalytic converter to reduce cold start condition exhaust emissions. Using electrical heaters is one method for reducing cold start emissions. Due to stringent emission legislations, this method may be implemented in internal combustion engines in vehicles in the near future.

\section{DECLARATION OF CONFLICT}

We have no conflict of interest.

\section{ACKNOWLEDGMENTS}

The authors would like to thank the Scientific Technological Research Council of Turkey (TÜBITTAK). This work was supported by the Scientific Technological Research Council of Turkey under the Grant of Support Programme for Scientific and Technological Research Project (Project Code: 112M156).

\section{REFERENCES}

Bhaskar K., Nagarajan G. and Sampath S., 2010, Experimental Investigation On Cold Start Emissions Using Electrically Heated Catalyst in A Spark Ignition Engine, International Journal of Automotive and Mechanical Engineering, 2, 105-118. 
Bhattacharyya S. and Das, R.K., 1999, Catalytic Control of Automotive $\mathrm{NO}_{\mathrm{x}}$ : a Review, Int. J. Energy Res., 23, 351-369.

Coppage, G.N. and Bell, S.R., 2002, Use of an Electrically Heated Catalyst to Reduce Cold-Start Emissions in a Bi-Fuel Spark Ignited Engine, J. Eng. Gas Turbines Power, 123, 125, doi:10.1115/1.1340640.

Dinler N., Aktas F. and Yucel, N., 2018, Effects of channel design and temperature on the performance of the catalytic converter, Int. J. Green Energy, 15, 813-820, doi:10.1080/15435075.2018.1529578.

Durat M. , Parlak Z. , Kapsız M. , Parlak A. and Fıçıcı F., 2013, Bir Buji Ateşlemeli Motorun Egzoz Sisteminin Termal Performasının CFD ve Deneysel Analizi. Is Bilimi ve Tekniği Dergisi. 33(2): 89-99.

Gong C., Huang K., Deng B. and Liu X., 2011, Catalyst light-off behavior of a spark-ignition LPG (liquefied petroleum gas) engine during cold start, Energy, 36, 5359, doi:10.1016/j.energy.2010.11.026.

Guerrero L.M., Mendoza J.F., Ong K.T.V., OlegarioSanchez E.M. and Ferrer, E.L., 2019, Copper-Exchanged Philippine Natural Zeolite as Potential Alternative to Noble Metal Catalysts in Three-Way Catalytic Converters, Arab. J. Sci. Eng., 44, 5581-5588, doi:10.1007/s13369-019-03882-y.

Guojiang W. and Song T., 2005, CFD simulation of the effect of upstream flow distribution on the light-off performance of a catalytic converter, Energy Conversion and Management, 46, 2010-2031, doi:10.1016/j.enconman.2004.11.001.

Heywood J.B., 1988, Internal Combustion Engine Fundamentals, McGraw-Hill.

Horng R.-F., Chou H.-M. and Hsu T.-C., 2004, Effects of heating energy and heating position on the conversion characteristics of the catalyst of a four-stroke motorcycle engine in cold start conditions, Energy Conversion and Management, 45, 2113-2126, doi:10.1016/j.enconman.2003.10.012.

Iliyas A., Zahedi-Niaki M.H., Eić M. and Kaliaguine S., 2007, Control of hydrocarbon cold-start emissions: A search for potential adsorbents, Microporous Mesoporous Mater., 102, 171-177, doi:10.1016/j.micromeso.2006.12.038.

Kalam M.A. and Hassan M.H., 2011, Design, Modification and Testing of a Catalytic Converter for Natural Gas Fueled Engines, Arab. J. Sci. Eng., 36, 677688, doi:10.1007/s13369-011-0078-0.

Kandylas I.P. and Stamatelos A.M., 2000, The behaviour of aged three-way catalytic converters in the different modes of legislated cycles, Int. J. Energy Res., 24, 425442.
Koltsakis G., 1997, Catalytic automotive exhaust aftertreatment, Prog. Energy Combust. Sci., 23, 1-39, doi:10.1016/S0360-1285(97)00003-8.

Lafyatis D.S., Ansell G.P., Bennett S.C., Frost J.C., Millington P.J., Rajaram R.R., Walker A.P. and Ballinger T.H., 1998, Ambient temperature light-off for automobile emission control, Appl. Catal. B Environ., 18, 123-135, doi:10.1016/S0926-3373(98)00032-0.

Mahadevan G. and Subramanian S., 2017, Experimental Investigation of Cold Start Emission using Dynamic Catalytic Converter with Pre-Catalyst and Hot Air Injector on a Multi Cylinder Spark Ignition Engine, $S A E$ Technical Paper 2017-01-2367, doi:10.4271/2017-012367.

Pulkrabek W.W., 2004, Engineering Fundamentals of the Internal Combustion Engine, New Jersey, Pearson Prentice Hall.

Ramanathan K., West D.H., Balakotaiah V., 2004, Optimal design of catalytic converters for minimizing cold-start emissions, Catalysis Today, 98, 357-373, doi:10.1016/j.cattod.2004.08.003.

Roberts A., Brooks R. and Shipway P., 2014, Internal combustion engine cold-start efficiency: A review of the problem, causes and potential solutions, Energy Conversion and Management, 82, 327-350, doi:10.1016/j.enconman.2014.03.002.

Sendilvelan S. and Bhaskar K., 2016, Experimental analysis of catalytic converter for reducing environmental pollution from SI engine using electrically initiated and chemically heated catalyst, ARPN J. Eng. Appl. Sci., 11, 13735-13739.

Shah A.N., Ge Y. Shan and Jiang L., 2011, Impact of a Urea-Selective Catalytic Reduction System on Volatile Organic Compound Emissions from a Diesel Engine, Arab. J. Sci. Eng., 36, 891-901, doi:10.1007/s13369011-0072-6.

Tyagi R.K. and Ranjan R., 2015, Effect of heating the catalytic converter on emission characteristic of gasoline automotive vehicles, Int. J. Ambient Energy, 36, 235241, doi:10.1080/01430750.2013.853205. 